\title{
Splitting up Dhaka City: Rationales, Challenges and Prospects as a Sustainable City
}

\author{
Md Wahid Murad \\ UniSA College \\ University of South Australia \\ Adelaide, SA 5001, Australia \\ E-mail: wahid.murad@unisa.edu.au \\ Md. Mahmudul Alam* \\ School of Economics, Finance \& Banking \\ Universiti Utara Malaysia \\ Sintok, Kedah, Malaysia \\ E-mail: rony000@gmail.com \\ Shawon Muhammad Shahriar \\ Institute for Environment and Development \\ National University of Malaysia \\ Bangi, Selangor, Malaysia \\ E-mail: shawon.shahriar@gmail.com \\ * Corresponding author
}

\section{Citation Reference:}

Murad, M.W., Alam, M.M. \& Shahriar, S.M. (2021). Dhaka City Split Up: Rationales, Challenges and Prospects as a Sustainable City. International Journal of Innovation and Sustainable Development, $15(3), \quad 322-335 . \quad$ (online) https://www.doi.org/10.1504/IJISD.2021.10038215

This is a pre-publication copy.

The published article is copyrighted by the publisher of the journal. 


\title{
Splitting up Dhaka City: Rationales, Challenges and Prospects as a Sustainable City
}

\begin{abstract}
The objective of this study is to analyse the rationales, challenges and prospects of Dhaka City being split up, for the purposes of creating a sustainable city grounded in relevant theories and widely used and accepted standards. An assessment of Dhaka being divided in accordance with the concept of City Development Strategies reveals considerable deficiencies in most aspects of public goods and services provisions. Whilst splitting Dhaka into separate sections supports the "World City Hypothesis" it is not without criticisms, for instance those raised by urban planners, experts and politicians. The lack of resources and oversight to address those deficiencies and problems and the administrative, allocative, economic and social inefficiencies makes it very difficult for Dhaka's authorities to achieve sustainable urbanisation. Therefore, appropriate strategies must be implemented by government to resolve these problems, inefficiencies and mismanagement in order for the city to be liveable sustainable.
\end{abstract}

Key words: Dhaka city; Sustainable city; City split; City development strategies; Sustainable urbanization; World City Hypothesis

\section{Introduction}

Presently, half of the world's megacities are located in the Asia-Pacific region, and of the 10 that exist, Asia has 7 (UN-HABITAT, 2010). Dhaka, the capital of Bangladesh, is well known as the fastest growing megacity in the world (German and Pyne, 2010). The estimated current population of Dhaka is 15.39 million (United Nations, 2012) and it is ranked $9^{\text {th }}$ among the world's megacities (World Bank, 2010). During the last four decades, Dhaka has recorded phenomenal growth in both population and area (United Nations, 2006). Although Dhaka's growth rate has declined slightly in recent years, the United Nations still projects that by 2025 it will have grown into the world's eighth largest city with a population of around 23 million (United Nations, 2012). Dhaka's 14.65 million people live just in area covering only $325 \mathrm{~km}^{2}$. At more than 45,000 people per $\mathrm{km}^{2}$, the capital of Bangladesh is nearly $75 \%$ denser than Hong Kong (Cox, 2012). According to City Mayors Statistics, the GDP of Dhaka in 2005 was \$52 billion and growing annually at $6.1 \%$.

The projected GDP of Dhaka in the year 2020 is \$126 billion (District Statistics (2011). The annual per capita income of the city is estimated at $\$ 1,350$, with $34 \%$ of households living below the poverty line (Asian City Development Strategies, 2000). According to Bangladesh Poverty Maps (2010), the poverty rate in the Dhaka city is $30.5 \%$ while Forbes Media (2013) estimated the per capita GDP of Dhaka's residents at US\$3,100. Describing the current status of Dhaka in its Development Series paper, the World Bank (2007, p. xiii) stated at length:

The country does not have a comprehensive policy on urbanisation and urban poverty. There are between 16 and 40 different bodies involved in one way or another in urban matters in Dhaka with little coordination and planning. As a result, there are major gaps in services and infrastructure ranging from weak electrical supply to inadequate land and housing options, and major traffic congestion. The poor are particularly affected as they do not have the resources to find alternatives for meeting their basic needs. While a new committee for Urban Development was set up and has achieved some progress in the coordination process, it focuses on solving day-to-day problems and not on medium to long term strategy. 
However, urban planners and city administrators have always encountered challenges in ensuring equitable growth for Dhaka, partly because of certain unique and challenging characteristics of urbanisation in Bangladesh. As much as $60 \%$ of the country's urban population live in only four cities and are at risk of natural disaster and climate change impacts (Intellecap, 2012). In Dhaka, the country's capital, 37\% of its population live on 5\% of available land (Intellecap, 2012). The average population density in the city's slums is 831 persons per acre, which is seven times higher than the national average (Hossain, 2014). Further compounding the problem, only 5-6\% of the city has roads compared to the worldwide average of $25 \%$, thus causing severe traffic congestion (Intellecap, 2012).

Mismanagement and lack of vision by city administrators also contribute to the hard lives of Dhaka's dwellers. From the infrastructure perspective, roads are in dilapidated condition, pavements are either missing or illegally occupied by street vendors, traders and house builders and public transport facilities fail to meet the demands of an ever-burgeoning population. The April 2013 Rana Plaza collapse in Savar, a sub-district of the greater Dhaka area, resulted in an official death toll of 1,127 and injuries suffered by approximately 2,500 garment workers. With many more people working in the building still unaccounted for. This tragedy tells us how vulnerable the migrant poor and marginalised communities in the city are. City growth is resulting in split up, which we consider as an emerging and important trend, especially in developing countries like Bangladesh.

There is also a severe crisis of utility services like water, gas and electricity (Imam, 2011). Against the backdrop of these ongoing dangers, the government of Bangladesh decided to amend the Local Government (City Corporation) Act 2009 and split Dhaka into two administrative zones, Dhaka North and Dhaka South (see Figure 1) in November 2011. Our observation reveals that even before Dhaka was split up the city authorities had to deal with many socioeconomic, political and demographic challenges. The same circumstances we observed for the city's inhabitants who have to endure many problems including lack of access to public amenities and utilities, among others (Alam et al., 2020). The city authorities and officials were also blamed for corruption, inefficiencies and mismanagement in all aspects of their administration, management and service provision. This study critically analyses the rationales, challenges and prospects of Dhaka City being split up so that it is a sustainable city. It also provides a brief assessment of the Dhaka city split up strategy in terms of sustainable urbanisation and effective City Development Strategies. We also investigated the applicability of the "World City Hypothesis" to the Dhaka split up. We believe that this assessment will complement into our efforts to address the above research questions in a comprehensive and coherent way. 


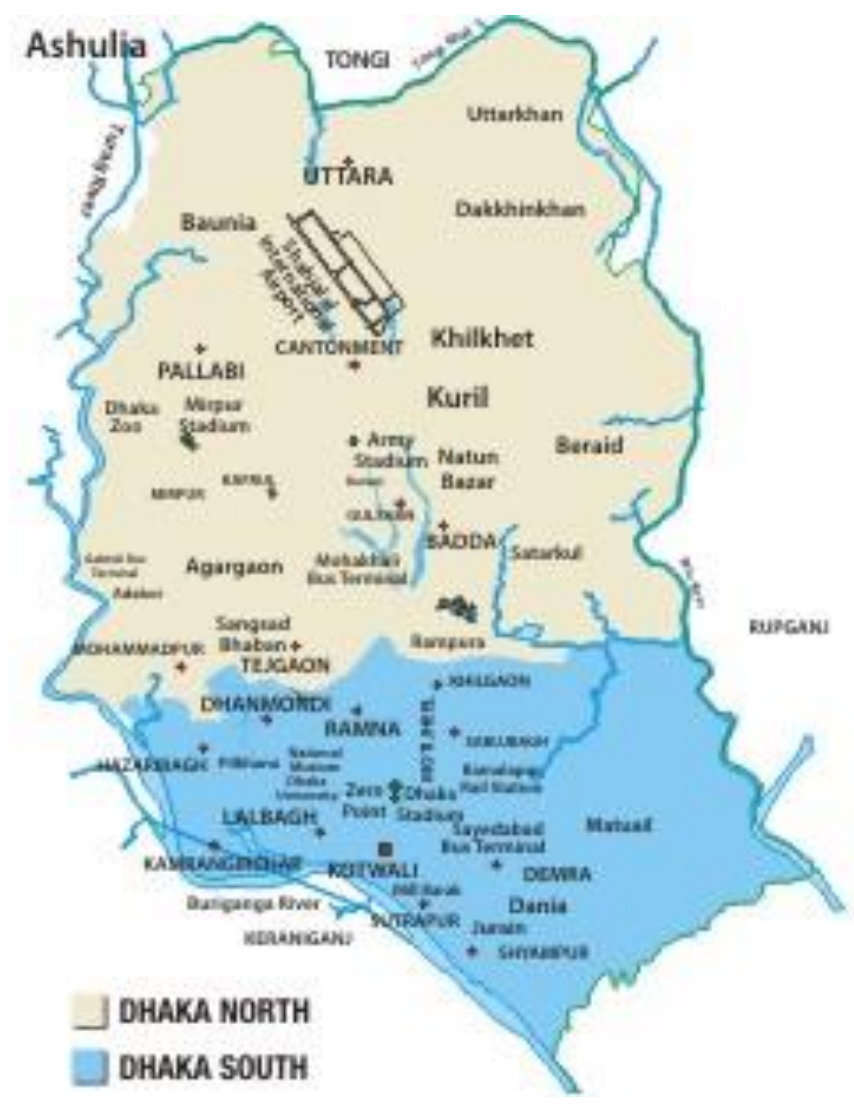

Figure 1. Map of Dhaka following the split in 2011 (Source: The Daily Star, 2011)

\section{Theoretical Underpinning and Literature Review}

There are empirical cases in which the splitting up of cities is supported by scholars because it is deemed to be good. Many scholars have discussed and debated the issue of splitting up cities, a phenomenon that is driven by politics, economics and geographical circumstances (Brenner, 2004a, 2004b; Keating, 1998, 2001). The splitting up process is also relevant within large metropolitan cities because it is suggested that the division of administrative units into small or sub-units will result in better decisions being made and implemented (Denters and Rose, 2005; Stoker, 2004). The concept of merging boundaries to create an all-encompassing administrative system for large cities is now considered obsolete (Bish, 2001). However, in the latter half of the $20^{\text {th }}$ century, many of the world's biggest cities, for example Tokyo, Toronto, New York, Shanghai, and Hong Kong, resorted to the amalgamation approach to encourage growth and development but also centralise authority in how those cities were governed (Savitch \& Vogel, 2000, 2006). For instance, metropolitan reforms including amalgamation of boundaries, and transformation and reestablishment of administrative units took place in answer to perceived contemporary needs. In 1998, for example, Toronto Metro was merged with Toronto, London expanded into Greater London in 2000, and many administrative wards were assimilated with central Tokyo in 1998. All of these represent good examples of largescale changes in metropolitan administration.

However, hierarchical governance in a large metropolitan area is being questioned. The development of regional governments is believed to be a balanced set-up in Western economies 
where better strategic development is now emphasised. A good example of this arrangement is the establishment of the Greater London Authority (Lefe'vre, 1998). Similarly, Toronto adopted the amalgamation of the metropolitan areas and city from the former hierarchical setup. Other examples of this trend are Hong Kong, Shanghai and Tokyo where large-scale administrative processes are operating. However, in practice, the boundaries of a metropolitan city depend on the scale of urbanisation. Since scale of urbanization is basically unlimited, we observe a regular inclination to integrate urbanisation into the metropolitan boundaries by developing a theoretically harmonious governance mechanism. Thus, the purpose of amalgamation is to address and provide infrastructure and services beyond the borders of a single city, region, and state (Vogel, 2010).

With worldwide globalisation increasing in momentum, research on metropolitan cities has continued in the last few decades (Douglass, 2000; Friedmann and Wolff, 1986; Friedmann, 1988; Clark, 1996; Godfrey and Zhou, 1999; Hill and Kim, 2000; Knox and Taylor, 1995; Lo and Yeung, 1996; Sassen, 1991; Sharpe, 1995; Short et al., 1996; Taylor, 1997). However, the literature is silent on whether the growth and development and rising populations of the world's megacities, especially in developing Asia, is triggering the pressures on them to split. What we observed is that, with reference to the splitting up of megacities, ample studies have ranked global cities based on economic characterisation. This undermines the issue of sustainable urbanism and quality of life. Some exceptions to this scholarly trend are analyses by Douglass (2000), Lo and Marcotullio (2000, 2001) and Marcotuillio (2001) who discussed living standards and urban sustainability issues in the cities, but not from the context of a city splitting up.

The literature also shows that only a few scholars have studied sustainable development of the world's largest cities, especially the challenges of sustainability in Asia ( $\mathrm{Ng}$ and Hills, 2003; Douglass, 2000, p. 2326), globalisation and urban sustainability (Lo and Marcotullio, 2000, 2001). However, as Marcotullio (2001, p. 577) argues, "the process of achieving urban sustainable development is uncharted". Despite the major metropolitan cities in Asia such as Tokyo, Shanghai, Hong Kong, Taipei, and Singapore leading the global economic race, sustainable urban development remains their greatest challenge ( $\mathrm{Ng}$ and Hills, 2003). The literature on Dhaka and specifically its sustainability and quality of life issues is also surprisingly thin. Despite a proliferation in the literature on Dhaka, most of these studies focus on the slum and squatter populations, and not the issue of sustainability (Hossain, 2013).

Friedmann (1988) disagrees with the concept of amalgamation and advocates splitting up of cities to advance administrative effectiveness. He also emphasises the economic, social and political causes that lead to physical restructuring of cities. Discussions in the previous section reveal that splitting up Dhaka has divided the nation and resulted in political conflicts between the government and opposition parties. As well, delivery of public services has sharply declined due to the predominance of 'stand-over tactics' or other methods of exerting influence employed by local leaders, party members, and ward commissioners. All these individuals work with officials to form an oligarchy that rakes in money through corruption, which deprives the general public of basic urban services (Hossain, 2013). Corruption, crime, lack of law and order, political killings suppression of media reporting and people's rights in Dhaka constitute the major news headlines of Bangladesh newspaper dailies. It is evident that the city is not functioning as expected. In other words, Dhaka has descended into a megacity where organized crime is rife and where only the affluent classes benefit financially, socially, and environmentally (Hossain, 2013). 
Class struggle remains acute among the poorer sections living in Dhaka. The rightful demands made by people against the capitalists are being targeted and largely suppressed through paid gangs. These groups are alleged to have close links with political leaders - a popular malpractice among oligarchic groups (Hossain, 2013). However, our observation based on a globally comprehensive literature review suggests that the splitting up of cities in the world's developed countries has achieved administrative, allocative, economic and social efficiencies. In those countries, the problem of splitting up metropolitan governance often turns up as obvious threat that may reduce the competitiveness of regional economy (Benjamin and Nathan, 2001; Brenner, 2004a, 2004b). An example of not splitting up - due to its comprehensive metropolitan features - is New York which still offers a high level of economic competitiveness globally. On the other hand, Branscomb (2006) asserted that a city's growth and decay often outpace each other. To ensure quality living standards of citizens, proper planning and investment are required, and where they are not evident, these can lead to an unsustainable city.

\section{Materials and Method}

This is a conceptual research study undertaken using key library materials such as relevant journal articles, book chapters, conference papers, monographs, etc., to substantiate the authors' arguments and achieve the study's objectives. Some qualitative data used is secondary in nature, and they have been referenced where applicable. Except those have been referenced duly all other arguments and analysis are of the authors' own. No primary source data or other quantitative tools and techniques have been used in the study. In the present study, we used the City Development Strategies (CDS) concept, which has been defined by the World Bank and UN-Habitat (sourced from ECON Analysis \& Centre for Local Government, UTS, 2005). We also referred to certain aspects of sustainable urbanisation, which have been outlined by Saha and Paterson (2008). The above two criteria serve to briefly assess the level of sustainable urbanisation and quality of life in two Dhaka cities, i.e. Dhaka North and Dhaka South.

\section{Discussion}

This section provides a critical discussion of Dhaka's splitting up based on the possible challenges this situation will encounter, and relevant theories that are applicable to it. The aim is to evaluate the splitting up of Dhaka in the contexts of sustainable urbanisation and quality of life issues. The last part of this section briefly analyses the "World City Hypothesis" which was postulated by distinguished urban planners Friedmann and Wolff (1986), and whether it can be applied to of the splitting up of Dhaka. We believe that any splitting up of a megacity such as Dhaka does not have only major implications in terms of sustainable urbanisation and quality of life issues but will also result in various economic development and political consequences. This is because any such move is sometimes triggered by short-term political objectives of the government that initiated the split.

\section{Challenges for a Divided Dhaka}

The decision and subsequent implementation of splitting Dhaka city into two different and separate administrative zones was a challenging one from the perspective of benefiting the city dwellers. The main rationale was that with a smaller city area to serve, each DCC's 
governance would improve and better civic participation could be ensured. However, the rationale is not ideal for an inclusive city concept. This is because splitting up a city may have serious consequences for civic services, management of urban features, natural resources use and preservation, and future growth (Morshed, 2011). In this section we discuss some major challenges that the divided Dhaka cities might experience due to important political, socioeconomic and demographic factors. Our discussion of those challenges has been substantiated by recent and relevant studies.

\section{Electoral Politics}

It is often problematic when an elected mayor either of Dhaka North City Corporation (DNCC) or Dhaka South City Corporation (DSCC) is from the opposition party. Due to the political affiliations of a mayor, the administrative processes and decisions are more likely to show signs of favouritism or preferred deals, thus forcing the ruling political party of the country to intervene when its interests are not being served. As per the existing political norms of Bangladesh, elected representatives from the ruling party have plenty of resources and the perquisites of office, while the representatives from the opposition party lack the necessary resources and administrative tools to be effective. So, if one part of Dhaka receives preferential treatment over the other due to this kind of electoral politics, the city will degenerate into a permanently fragile and divisive urban system (Morshed, 2011).

\section{Visions and Strategies}

Even if both mayors of the two Dhaka city corporations are affiliated with the same political party, they could develop and promote their own strategic visions for city management and development. Historically, the great physical development of cities has always been linked to urban administrators whose dynamic vision is backed with authorised power. In the late 1980s, for example, sustainable urbanism was initiated in South America by the mayor Jaime Lerner, who also implemented reforms for the southern Brazilian city of Curitiba. The problem of managing municipal waste appeared as the most challenging issue to the mayor when he took charge of office. A massive pile up of household waste on the narrow roads became a major public health concern. It was almost impossible to collect municipal waste because the waste removal vehicles could not enter the narrow streets. The mayor came up with a new and innovative idea of exchanging trash bags for bus passes. The program generated tremendous success for the mayor in cleaning up the city, which also induced more people to use the rapidtransit system (Morshed, 2011). The visionary administrator is, therefore, crucial to the design of a sustainable and vibrant metropolitan city. This person does not merely focus on providing services, but ensures quality of education, health and accommodation at an affordable cost. The administrator is also concerned for ensuring good urban ecology that offers sufficient recreational green and blue spaces for the city's residents (Morshed, 2011). With two Dhaka city mayors in office but having very different aims, this will challenge urban planners in developing a comprehensive urban strategy for the entire city and implementing it accordingly.

\section{Centralized City Governance}

Although Dhaka City Corporation (DCC) has been divided into DSCC and DNCC, no change has been made to the existing top-down and centralised city governance model. The two city corporations are now divided into many wards (political units), while the ward councillors do not have enough responsibilities and authority. If these wards can be administered according to modern concepts of governance, Dhaka could have better planning, infrastructure management and services. However, the lower administrative units such as the wards cannot deliver the benefits of local government as it is supposed to do throughout the 
country. The simple reason is that ward councillors do not - or are not encouraged to participate in ward planning, infrastructure management and services (Ahsan, 2011). The end result is a continuation of an inefficient city governance model.

\section{Corruption and Mismanagement}

An administration can run efficiently if it ensures good governance and zero corruption. The size of the organisation does not matter but the quality does matter the most. The quality of administration delivered by an organisation is a system where employees work with honesty, integrity, fair-mindedness, and dedication at all levels of governance. Yet many residents in Dhaka struggle to obtain access to minimum public amenities due to widespread corruption or maladministration. The 'under-the-table' practices are a normal routine event for officials and administrators who normally do not entertain clients unless 'seed' or 'speed' money is paid to them for services to be delivered. It is not the size of the city area or the population density that is important to inhabitants; they are more concerned about corruption and mismanagement practiced by public officials (Imam, 2011). Without any substantial changes in the system and how human resources are employed, the old challenges remain in place resulting in deprivation of resources and public amenities for the city residents and inefficiencies in the city management and administration.

\section{The Terrain and Demographic Patterns of Dhaka}

Dhaka, as one of the most densely populated cities of the world, is virtually surrounded by rivers that limit its expansion. Even dividing the city into more administrative units does not solve the continual challenges due to its physical features and anthropogenic pressures that exist every day. The future and unregulated growth of the population of Dhaka already prevents the administrators from achieving anything substantial, due to lack of resources and inefficient services that compromise traffic management, waste management and healthy environment. This resonates with Islam (2012) who states that Dhaka provides a fascinating site for understanding these complexities of emerging urban life. Consequently, no miracle should be expected in the delivery of services (Choudhury, 2011).

\section{Aspects of Sustainable Urbanisation}

Likewise, if we assess the two cities of Dhaka in line with the three key aspects of sustainable urbanisation, these being environmental protection, economic development and social and justice equity (Saha and Paterson, 2008) in Table 1, both Dhaka North and Dhaka South would largely fail those sustainability aspects. Out of fourteen criteria for environmental protection, eleven criteria for economic development and eleven criteria for social justice and equity as integrated into the aspects of sustainable urbanisation, the two Dhaka cities do not pass one single criterion for sustainable urbanisation or development. Apparently, considerable deficiencies on the part of both Dhaka North and Dhaka South city authorities exist in all three aspects of sustainable urbanisation. Therefore, the authorities of the two Dhaka cities must work together or cooperate at some level to produce considerable improvements in all three aspects of urbanisation. Strongly related to this is the need to formulate bipartisan policies and strategies and implement them effectively to ultimately achieve objectives that Dhaka greatly needs.

Table 1: Aspects of Sustainable Urbanisation 


\begin{tabular}{|c|c|c|c|c|c|}
\hline 1. & $\begin{array}{l}\text { Alternative energy offered to } \\
\text { consumers }\end{array}$ & 1. & Agricultural protection zoning & 1. & $\begin{array}{l}\text { Affordable housing } \\
\text { provisions }\end{array}$ \\
\hline 2. & $\begin{array}{l}\text { Energy conservation effort } \\
\text { (other than green building } \\
\text { requirements) }\end{array}$ & 2. & Brownfield reclamation & 2. & $\begin{array}{l}\text { Day-care services for service } \\
\text { sector and low-income } \\
\text { employees }\end{array}$ \\
\hline 3. & $\begin{array}{l}\text { Environmental site design } \\
\text { regulations }\end{array}$ & 3. & $\begin{array}{l}\text { Cluster or targeted economic } \\
\text { development }\end{array}$ & 3. & $\begin{array}{l}\text { Homeless prevention and } \\
\text { intervention programs }\end{array}$ \\
\hline 4. & Green building program & 4. & $\begin{array}{l}\text { Eco-industrial park } \\
\text { development }\end{array}$ & 4. & $\begin{array}{l}\text { Inclusionary and incentive } \\
\text { zoning }\end{array}$ \\
\hline 5. & $\begin{array}{l}\text { Renewable energy use by } \\
\text { city government }\end{array}$ & 5. & Infill development & 5. & Jobs-housing balance \\
\hline 6. & Curb side recycling program & 6. & $\begin{array}{l}\text { Purchase of development } \\
\text { rights and/or transfer of } \\
\text { development rights }\end{array}$ & 6. & Living wage \\
\hline 7. & $\begin{array}{l}\text { Environmental education } \\
\text { programs for the community }\end{array}$ & 7. & $\begin{array}{l}\text { Tax incentives for } \\
\text { environmentally friendly } \\
\text { development }\end{array}$ & 7. & $\begin{array}{l}\text { Mass transit access with } \\
\text { local income subsidies }\end{array}$ \\
\hline 8. & Green procurement & 8. & $\begin{array}{l}\text { Urban growth boundary } \\
\text { and/or urban service boundary }\end{array}$ & 8. & Neighborhood planning \\
\hline 9. & Water quality protection & 9. & Business retention programs & 9. & $\begin{array}{l}\text { Sustainable food systems or } \\
\text { food security programs }\end{array}$ \\
\hline 10. & $\begin{array}{l}\text { Environmentally sensitive } \\
\text { area protection }\end{array}$ & 10. & $\begin{array}{l}\text { Empowerment/enterprise } \\
\text { zones }\end{array}$ & 10. & $\begin{array}{l}\text { Women/minority-oriented } \\
\text { business Community } \\
\text { Development Corporations } \\
\text { (CDCs) and investment } \\
\text { programs }\end{array}$ \\
\hline 11. & $\begin{array}{l}\text { Open space preservation } \\
\text { program }\end{array}$ & 11. & $\begin{array}{l}\text { Local business incubator } \\
\text { programs }\end{array}$ & 11. & $\begin{array}{l}\text { Youth opportunity and anti- } \\
\text { gang programs }\end{array}$ \\
\hline 12 . & $\begin{array}{l}\text { Operation of inner-city } \\
\text { public transit (buses and/or } \\
\text { trains) }\end{array}$ & & & & \\
\hline & $\begin{array}{l}\text { Transportation demand } \\
\text { management }\end{array}$ & & & & \\
\hline 14. & Ecological footprint analysis & & & & \\
\hline
\end{tabular}

Source: Saha and Paterson, 2008.

\section{City Development Strategies (CDS)}

We argue that an assessment of the greater Dhaka city, including Dhaka North and Dhaka South, in terms of the City Development Strategies (CDS) as defined by the World Bank and UN Habitat (Table 2) will result in large deficiencies where the city authorities have failed. Unless effective city development strategies are devised and then implemented accordingly, the splitting up of Dhaka into two cities will not reduce or solve those deficiencies. Therefore, what the two Dhaka cities' authorities need to do is to first formulate meaningful strategies by aligning them with CDS and then implementing them without fear or favour.

Table 2: Themes of City Development Strategies (CDS) defined by the World Bank and UNHabitat

\begin{tabular}{|c|c|}
\hline The World Bank & UN-Habitat \\
\hline $\begin{array}{l}\text { Liveability: the poor achieve a healthy and dignified } \\
\text { living standard }\end{array}$ & $\begin{array}{l}\text { Shelter: Adequate housing and basic services; } \\
\text { security of tenure; access to land and credit }\end{array}$ \\
\hline \multirow{4}{*}{$\begin{array}{l}\text { Competitiveness: buoyant, broad-based growth of } \\
\text { employment, incomes and investment }\end{array}$} & Social Development and Eradication of Poverty: \\
\hline & Equal opportunities for a safe and healthy life; social \\
\hline & $\begin{array}{l}\text { integration; support for disadvantaged groups; gender } \\
\text { equality }\end{array}$ \\
\hline & \\
\hline
\end{tabular}


Good governance: inclusion and representation of all groups in the urban society; accountability, integrity and transparency of local government

Bankability: sound financial management of local government
Economic Development: Stronger small and micro enterprises; public/private partnerships; access to productive employment

Governance: Participation and civic engagement; transparent, accountable and efficient governance; sound financial management; decentralization and strong local authorities

Environmental Management: Balanced settlement structures; water management; reducing pollution; disaster prevention; environmentally sound transport, etc.

Source: ECON Analysis \& Centre for Local Government, UTS (2005).

\section{Applicability of the "World City Hypothesis" to the Dhaka City Split Up}

The "World City Hypothesis" was first proposed in 1986 by the urban planner John Friedmann. According to this hypothesis, the formation of a world city put increased polarisation of urbanisation processes and creates a new international division of labour. Consequently, the problem of polarisation yields social costs at rates that tend to exceed the fiscal capacity of the state to afford. While the splitting up of Dhaka supports the above hypothesis, it is not without criticisms such as the ones raised by urban planners, experts and politicians. The current government has cited inefficient coordination and lack of adequate autonomy as the reason for splitting up the city into two because of its vast size. Yet the facts are considerably different when referring to coordination and autonomy. Specifically, the government authorities of Dhaka North and Dhaka South have simply failed to provide services adequately and efficiently. For example, the semi-autonomous organisations, such as Dhaka Electric Supply Authority (DESA), Dhaka Water and Sewerage Authority (DWASA), Rajdhani Unnayan Kortiporko (RAJUK, i.e. Dhaka Development Authority) and Dhaka Metropolitan Police (DMP) enjoy little autonomy and are noted for their corruption and inefficiency (Hossain, 2013). While proper coordination of government entities with all stakeholders should be enough to conduct better administrative services for a large city, this principle is absent in Dhaka (Hossain, 2013). In fact, most of the world's prominent metropolitan centres have well-ordered, structured, and financed governance mechanisms that ensure things get done with no great cost to economic, social, cultural, and technological aspects. Other great cities of the world are able to provide well-equipped services to the citizens and still sustain the urban environment ( $\mathrm{Ng}$ and Hills, 2003). However, on every count Dhaka city fails to provide administrative services and living environments adequately and efficiently for its inhabitants. The city cannot solve new challenges if current ones are being ignored.

\section{Conclusions}

This study looked at an increasingly important issue which has not been addressed by other studies in great detail thus far. Our main contribution lies in addressing to the situation of Dhaka, a megacity and the capital city of Bangladesh, being split into two. We believe that splitting Dhaka into two separate cities is adding further complexities to already unaddressed problems and inefficiencies in how it is administered and this impact on the populace. The city authorities' lack of resources means that they cannot address those problems properly and their administrative, allocative, economic and social inefficiencies simply build up over time. Stringent decisions and appropriate strategies must be undertaken by Bangladeshi government to resolve those problems, inefficiencies and mismanagement in order to make Dhaka liveable and sustainable for its inhabitants. 
Our discussion of Dhaka looked at aspects of sustainable urbanisation, the concept of City Development Strategies and "World City Hypothesis". The results are not encouraging, and this is mainly due to the problems, challenges and administrative and (mis)management issues experienced by the Dhaka city authorities and the city inhabitants as discussed earlier. For the divided Dhaka, poor or non-existent city planning, corruption and unregulated development together with a huge migration of rural poor and marginalised communities into the city, are coupled with political motives behind splitting the city into two. This process undermines the capacities of the city authorities to realise administrative, allocative, economic and social objectives, both effectively and efficiently. In fact, cities like Dhaka are believed to be offering opportunities for all. Millions of rural people migrate to Dhaka city each year to seek a better livelihood and a materially richer life. Similarly, business opportunities are also attractive to the financial elites who want to establish creative businesses and ventures, but they tend to become involved in corrupt practices through their links to the elites controlling Dhaka North and Dhaka South. Therefore, while as a whole the city offers the hope of creating wealth to all, the reality is that it regularly fails to manage large populations whose demand for public services and amenities is growing.

\section{References}

Ahsan, B. (2011). Why slice city into two? The Daily Star, $27^{\text {th }}$ November 2011, Dhaka, Bangladesh (accessed: $17^{\text {th }}$ October 2017). [http://www.thedailystar.net/newDesign/news-details.php?nid=211838]

Alam, M.M., Hossain, M.S., Islam, N., Murad, M.W., \& Khan, N.A. (2020). Impacts of Health and Economic Costs on Street Children Working as Waste Collectors in Dhaka City. International Journal of Environment and Sustainable Development, forthcoming.

Asian City Development Strategies (2000). Dhaka (the People's Republic of Bangladesh). Fukuoka Conference 2000, Cities Alliance. (accessed 24 ${ }^{\text {th }}$ August 2017). [http://web.archive.org/web/20040909085826/http:/www.citiesalliance.org/fukuoka.n sf/Attachments/CP_Dhaka/\$File/CPF_Dhaka.PDF].

Benjamin, G., \& Nathan, R. P. (2001) Regionalism and realism: A study of governments in the New York Metropolitan Area. Washington, D.C.: Brookings Institution Press.

Bish, R. L. (2001). Local government amalgamations: Discredited nineteenth-century ideals alive in the twenty-first. C. D. Howe Institute Commentary, Yonge Street, Toronto, Ontario, Canada.

Branscomb, L. M. (2006). Sustainable cities: Safety and security. Technology in Society, 28 (2006): 225-234.

Brenner, N. (2004a). New state spaces: Urban governance and the rescaling of statehood. Oxford, UK: Oxford University Press.

Brenner, N. (2004b). Urban governance and the production of new state spaces in Western Europe, 1960-2000. Review of International Political Economy, 11(3): 447-488.

Choudhury, Z. (2011). The great partition of Dhaka city. The Daily Star, $6^{\text {th }}$ December 2011 , Dhaka, Bangladesh (accessed: 18 ${ }^{\text {th }}$ October 2017). [http://www.thedailystar.net/newDesign/news-details.php?nid=213013].

Clark, D. (1996). Urban World/Global City. London: Routledge.

Cox, W. (2012). Evolving urban form: Dhaka. Newgeography. (accessed $21^{\text {st }}$ January 2018). [http://www.newgeography.com/content/003004-evolving-urban-form-dhaka].

Denters, B., \& Rose, L. (Eds.) (2005). Comparing local governance: Trends and developments. Basingstoke, UK: Palgrave. 
District Statistics (2011). District Statistics 2012: Dhaka. Bangladesh Bureau of Statistics, Statistics and Informatics Division, Ministry of Planning, Government of the People's Republic of Bangladesh, Dhaka.

Douglass, M. (2000). Mega-urban regions and world city formation: globalization, the economic crisis and urban policy issues in Pacific Asia. Urban Studies, 37(12), 23152335.

ECON Analysis \& Centre for Local Government, UTS. (2005). The Impacts of City Development Strategies. ECON-Report No. 2005-063, Project No. 43100, Commissioned by The Cities Alliance, Oslo, Norway and Broadway, Sydney.

Friedmann, J., \& Wolff, G. (1986). World city hypotheses. Development and Change, 17(1), 69-84.

Friedmann, J. (1988). World city formation. In Life Space and Economic Space, pp 57-92. New Jersey: Transaction Books.

German, E., \& Pyne, S. (2010). Dhaka: fastest growing megacity in the world. Globalpost, $8^{\text {th }}$ September. $\quad$ (accessed $26^{\text {th }} \quad$ September 2017). [http://www.globalpost.com/dispatch/asia/100831/bangladesh-megacities-part-one].

Godfrey, B. J., \& Zhou, Y. (1999). Ranking world cities: multinational corporations and the global urban hierarchy. Urban Geography, 20(3): 268-281.

Hill, R. C., \& Kim, J. W. (2000). Global cities and developmental states: New York, Tokyo and Seoul. Urban Studies, 37(12): 2167-2195.

Hossain, B. (2014). Do the slum dwellers enjoy the basic constitutional and economic rights as a citizen in Bangladesh? Global Disclosure of Economics and Business, 3(3): 27-37.

Hossain, S. (2013). Social formations of the megacity of Dhaka: A review essay (Book Review). Cities, 30(2013): 252-254.

Imam, H. (2011). Two mayors for Dhaka city. The Daily Star, $1^{\text {st }}$ December 2011, Dhaka, Bangladesh (accessed: $17^{\text {th }} \quad$ October 2017). [http://www.thedailystar.net/newDesign/news-details.php?nid=212453].

Intellecap (2012). Splitting Dhaka: Model or Mistake? Future Challenges initiative of Bertelsmann Foundation for "Searchlight South Asia" Newsletter, $27^{\text {th }}$ February 2012, Germany (accessed: 16 $6^{\text {th }}$ October 2017). [http://futurechallenges.org/searchlight/splitting-dhaka-model-or-mistake/].

Islam, S. A. (2012). Dhaka: Social Dynamics of a Megacity (Book Review). South Asia: Journal of South Asian Studies, 35:4, 885-892.

Keating, M. (1998). The new regionalism in Western Europe: Territorial restructuring and political change. Cheltenham, UK: Edward Elgar.

Keating, M. (2001). Governing cities and regions: Territorial restructuring in a global age. In A. J. Scott (Ed.), Global city-regions: Trends, theory, policy (pp. 371-390). Oxford, UK: Oxford University Press.

Knox, P. L., \& Taylor, P. J. (1995). World Cities in a World-System. Cambridge, UK: Cambridge University Press.

Lefèvre, C. (1998). Metropolitan government and governance in western countries: A critical review. International Journal of Urban and Regional Research, 22(1): 9-25.

Lo, F. C., \& Marcotullio, P. J. (2000). Globalization and urban transformations in the AsiaPacific Regions: A review. Urban Studies, 37(1): 77-111.

Lo, F. C., \& Marcotullio, P. J. (2001). Globalization and the Sustainability of Cities in the AsiaPacific Region. Tokyo: UNU Press.

Lo, F. C., \& Yeung, Y. M. (Eds) (1996). Emerging World Cities in Pacific Asia. Tokyo: United Nations University Press. 
Marcotullio, P. J. (2001). Asian urban sustainability in the era of globalization. Habitat International, 25(4), 577-598.

Morshed, A. (2011). A (problematic) tale of two Dhakas. www.bdnews24.com, $23^{\text {rd }}$ October 2011, Dhaka, Bangladesh (accessed: 15 th $^{\text {th }}$ October 2017). [http://opinion.bdnews24.com/2011/10/23/a-problematic-tale-of-two-dhakas/].

$\mathrm{Ng}$, M. K., \& Hills, P. (2003). World cities or great cities? A comparative study of five Asian metropolises. Cities, 20(3): 151-165.

Saha, D. \& Paterson, R. G. (2008). Local Government Efforts to Promote the "Three Es" of Sustainable Development Survey in Medium to Large Cities in the United States. Journal of Planning Education and Research, 28(1), 21-37.

Savitch, H. V., \& Vogel, R. K. (2000). Paths to the new regionalism. State and Local Government Review, 32(3): 158-168.

Savitch, H. V., \& Vogel, R. K. (2006). Local and regional governance: Rescaling the city. In E. Razin \& P. J. Smith (Eds.), Metropolitan governing: Canadian cases, comparative lessons (pp. 214-245). Jerusalem: Magnus Press.

Sassen, S. (1991). Global City: New York, London, Tokyo. Princeton, New Jersey: Princeton University Press.

Sharpe, L. J. (Ed.) (1995). The Government of World Cities: The Future of the Metro Model. Chichester, UK: John Wiley \& Sons.

Short, J. R., Kim, Y, Kuus, M., \& Wells, H. (1996). The dirty little secret of world cities research: data problems in comparative analysis. International Journal of Urban and Regional Research, 20(4): 297-716.

Stoker, G. (2004). New localism, progressive politics and democracy. The Political Quarterly, 75(1): $117-129$.

Taylor, P. J. (1997). Hierarchical tendencies amongst world cities: a global research proposal. Cities, 14(6), 323-332.

The Daily Star (2011). Mayor Khoka challenges DCC split. The Daily Star, $1^{\text {st }}$ December 2011, Dhaka, Bangladesh (accessed: $16^{\text {th }}$ October 2017). [https://www.thedailystar.net/newsdetail-212396].

United Nations (2006). World urbanization prospects: The 2005 revision. New York: United Nations. $\quad$ (accessed 18 December [http://www.un.org/esa/population/publications/WUP2005/2005WUPHighlights_Fina 1_Report.pdf].

United Nations (2012). World Urbanization Prospects: The 2011 Revision - Highlights. New York: Department of Economic and Social Affairs, Population Division, United Nations. $\quad$ 28 $8^{\text {th }} \quad$ October [http://esa.un.org/unup/pdf/WUP2011_Highlights.pdf]

UN-HABITAT (2010). The State of Asian Cities 2010/11. Regional Office for Asia and the Pacific, Japan: United Nations Human Settlements Programme (UN-HABITAT). (accessed 23 ${ }^{\text {rd }} \quad$ October 2017). [http://www.unescap.org/esd/apuf5/documents/SACR.pdf]

Vogel, R. K. (2010). Chapter 1: Governing global city regions in China and the West. In R. K. Vogel et al. (Eds.), Progress in Planning, 73 (2010): 1-75.

World Bank (2007). Dhaka: Improving Living Conditions for the Urban Poor. Bangladesh Development Series, Paper No. 17, The World Bank Office, Dhaka, June.

World Bank (2010). Country Assistance Strategy for the People's Republic of Bangladesh for the Period FY11-14. Dhaka: Bangladesh Country Management Unit South Asia Region and International Finance Corporation South Asia Department. 


\section{Author's Biography:}

Dr Md. Wahid Murad is currently a lecturer in economics and business at the University of South Australia. Previously, he worked at the University of Adelaide, South Australia and University of Malaysia Terengganu, Multimedia University in Malaysia in various positions, including lecturer, senior lecturer, head of economics discipline and an Associate Dean. Dr Murad has nearly 16 years of teaching experience and has been a researcher for over 21 years in Australia, and Malaysia. He has taught at undergraduate and postgraduate levels and supervised HDR students to completion. He has published a book, chapters in several books, and research articles in nearly 50 scholarly international journals in the areas of economic globalization, socioeconomics, tourism economics, environment, and development economics.

Dr. Md. Mahmudul Alam is a Senior Lecturer of Finance at Universiti Utara Malaysia, and a Research Fellow at Frankfurt School of Finance \& Management, University Technology MARA, and International Islamic University Chittagong. He obtained his $\mathrm{PhD}$ and Master's degrees in Environment and Development (Finance \& Economics) from National University of Malaysia. He has many publications, including 100 plus articles in refereed journals and five books/monographs. He has presented more than 70 articles at international conferences. He is recognized by BDRC as one of the "Top Bangladesh Development Researchers of the Millennium". His research areas include sustainable finance, sustainable development, ecological economics, financial economics and Islamic economics.

Mr. Shawon Muhammad Shahriar is currently a postgraduate student and a Graduate Research Assistant at the Institute for Environment and Development (LESTARI), National University of Malaysia (UKM). He obtained a BBA (Hons.) degree in Marketing from North South University (NSU), Bangladesh. Before joining at UKM, he worked with Grameenphone Limited, Dhaka, Bangladesh. His research areas include economic development, rural development, social institutions, marketing strategy, marketing policy, etc. 